www.nature.com/ja

\title{
New isochaetochromin, an inhibitor of triacylglycerol synthesis in mammalian cells, produced by Penicillium sp. FKI-4942: I. Taxonomy, fermentation, isolation and biological properties
}

\author{
Narihiro Ugaki ${ }^{1}$, Daisuke Matsuda ${ }^{1}$, Hiroyuki Yamazaki ${ }^{1}$, Kenichi Nonaka ${ }^{2}$, Rokuro Masuma ${ }^{2}$, Satoshi Ōmura ${ }^{2}$ \\ and Hiroshi Tomoda ${ }^{1}$ \\ A new bis-naphtho- $\gamma$-pyrone isomer named isochaetochromin $A_{1}$ was isolated along with known isochaetochromins $B_{1}$ and $B_{2}$ \\ from the culture broth of Penicillium sp. FKI-4942 by solvent extraction, silica gel column chromatography and HPLC. Among \\ them, isochaetochromin $B_{1}$ showed the most potent inhibitory activity of triacylglycerol synthesis with an $I_{50}$ value of $5.6 \mu \mathrm{M}$, \\ followed by isochaetochromins $B_{2}\left(I_{50}, 11 \mu \mathrm{m}\right)$ and $A_{1}(33 \mu \mathrm{m})$.
}

The Journal of Antibiotics (2012) 65, 15-19; doi:10.1038/ja.2011.105; published online 23 November 2011

Keywords: diacylglycerol acyltransferase; fungal metabolites; inhibitor; isochaetochromin; Penicillium; triacylglycerol biosynthesis; $\gamma$-pyrone

\section{INTRODUCTION}

Neutral lipids, triacylglycerol (TG) and cholesteryl ester (CE) are the final storage forms of free long-chain fatty acid and cholesterol in mammals. TG synthesis is important in many biological processes, including lactation, energy storage in adipose tissue and muscle, and fat absorption in the intestine. Excessive accumulation of TG in adipocytes as a result of a fat-rich diet or sedentary lifestyle causes obesity. The condition is also closely related to lifestyle-related diseases and metabolic syndrome. Recently, much attention has been paid to these disorders because of their current importance in health care. Several approaches have been evaluated for the treatment of obesity, and two drugs have been approved for use: sibtramine, which acts centrally to inhibit serotonin and noradrenaline uptake, ${ }^{1,2}$ and orlistat, which inhibits lipid lipase and therefore interferes with lipid absorption from the small intestine., ${ }^{3,4}$ One potential strategy for the treatment of obesity is to block TG synthesis; ${ }^{5}$ therefore, inhibitors of TG synthesis are expected to be therapeutic agents for obesity. ${ }^{6,7}$ TG is synthesized by a number of enzymes. ${ }^{8}$ Acyl-CoA: diacylglycerol acyltransferase $(\mathrm{DGAT})^{9}$ is the final enzyme to synthesize TG, and only a few DGAT inhibitors have been reported by several groups, including ours. ${ }^{10-14}$

We established a high content assay to observe the TG biosynthetic pathway using Chinese hamster ovary $(\mathrm{CHO}) \mathrm{K} 1$ cells. ${ }^{15}$ During our screening for inhibitors of TG synthesis, a new compound named isochaetochromin $A_{1}$ was isolated along with known isochaetochromins $B_{1}$ and $B_{2}{ }^{16}$ from the culture broth of Penicillium sp. FKI-4942 (Figure 1). These compounds are isomers having the same planar structure of bis-naphtho- $\gamma$-pyrone. ${ }^{16}$ In this study, the taxonomy of producing fungus, the fermentation, isolation and inhibitory activity against TG synthesis in CHO-K1 cells of isochaetochromins are described.

\section{MATERIALS AND METHODS}

General experimental procedures

Fungal strain FKI-4942 was originally isolated from a soil sample collected in the Bonin Islands, Tokyo, Japan. This strain was used for the production of isochaetochromins $A_{1}, B_{1}$ and $B_{2}$. Silica gel 60 (Merck, Darmstadt, Germany) was used for silica gel column chromatography. HPLC was carried out using the L-6200 system (Hitachi, Tokyo, Japan).

\section{Taxonomic studies of the producing strain FKI-4942}

Morphological studies and identification were conducted according to the procedures described by Pitt. ${ }^{17}$ For taxonomic studies, the strain was inoculated in three-point cultures on Czapeck yeast extract agar (CYA), malt extract agar (MEA) and 25\% glycerol nitrate agar (G25N), and then grown for 7 days at $25^{\circ} \mathrm{C}$ (also at $5^{\circ} \mathrm{C}$ and $37^{\circ} \mathrm{C}$ on CYA) in the dark. Morphological characteristics were observed under a scanning electron microscope (JSM-5600; JEOL, Tokyo, Japan). Color names and hue numbers were determined according to the Color Harmony Manual 4th Edition (Container Corporation of America, Chicago, IL, USA) ${ }^{18}$ For sequencing analysis, genomic DNA of the fungal strain FKI-4942 was extracted using the PrepMan Ultra Sample Preparation Reagent (Applied Biosystems, Foster City, CA, 


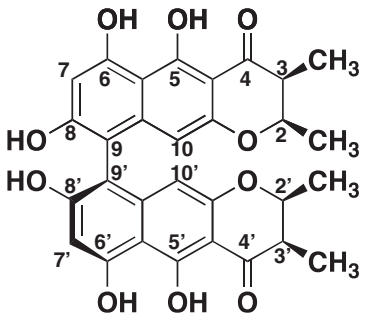

Isochaetochromin $\mathrm{A}_{1}$<smiles>CC1Oc2cc3c(-c4c(O)cc(O)c5c(O)c6c(cc45)OC(C)C(C)C6=O)c(O)cc(O)c3c(O)c2C(=O)C1C</smiles>

Isochaetochromin $B_{1}$<smiles></smiles>

Isochaetochromin $\mathrm{B}_{2}$

Figure 1 Structures of isochaetochromins $A_{1}, B_{1}$ and $B_{2}$.

USA) according to the manufacturer's instructions. The rDNA internal transcribed spacer regions, including the 5.8S rDNA were amplified by PCR using primers ITS1 and ITS4. ${ }^{19}$ Amplifications were performed using a PCR Verity 96-well thermal cycler (Applied Biosystems). PCR products were purified using a QIAquick PCR DNA Purification kit (Qiagen, Valencia, CA, USA). Sequencing reactions were directly performed in both directions using primers ITS1, ITS2, ITS3 and ITS4 with a BigDye Terminator v3.1 Cycle Sequencing Kit (Applied Biosystems), and the products were purified by ethanol/EDTA precipitation. DNA sequences were read on an ABI PRISM 3130 Genetic Analyzer (Applied Biosystems) and assembled using forward and reverse sequences with the programs SeqMan and SeqBuilder from the Lasergene8 package (DNAStar, Madison, WI, USA). The ITS sequence of the strain FKI-4942 was deposited in DDBJ (DNA Data Bank of Japan) with accession number AB588822.

\section{Fermentation media}

For the production of isochaetochromins, the seed medium contained $2.0 \%$ glucose, $0.50 \%$ polypeptone, $0.050 \% \mathrm{MgSO}_{4} \cdot 7 \mathrm{H}_{2} \mathrm{O}, 0.20 \%$ yeast extract, $0.10 \% \mathrm{KH}_{2} \mathrm{PO}_{4}$ and $0.10 \%$ agar, adjusted to $\mathrm{pH} 6.0$ before sterilization. The production medium was composed of $3.0 \%$ sucrose, 3.0\% soluble starch, $1.0 \%$ malt extract, $0.30 \%$ Ebios (Asahi Food \& Healthcare, Tokyo, Japan), $0.50 \% \mathrm{KH}_{2} \mathrm{PO}_{4}$ and $0.050 \% \mathrm{MgSO}_{4} \cdot 7 \mathrm{H}_{2} \mathrm{O}$, adjusted to $\mathrm{pH} 6.0$ before sterilization.

\section{Fermentation}

A stock culture of strain FKI-4942 was inoculated into a 500-ml Erlenmeyer flask containing $100 \mathrm{ml}$ seed medium and incubated on a rotary shaker ( 210 r.p.m.) at $27^{\circ} \mathrm{C}$ for 3.0 days. The production culture was initiated by transferring $1.0 \mathrm{ml}$ seed culture into a $500-\mathrm{ml}$ Erlenmeyer flask containing $100 \mathrm{ml}$ production medium, and fermentation was carried out on a rotary shaker $\left(210\right.$ r.p.m. ) at $27^{\circ} \mathrm{C}$ for 3.0 days and then under static conditions at $27^{\circ} \mathrm{C}$ for 10 days.

\section{Cell culture}

CHO-K1 cells were kind gifts from Dr K Hanada (National Institute of Infectious Diseases, Tokyo, Japan). Cells were maintained at $37^{\circ} \mathrm{C}$ in $5.0 \% \mathrm{CO}_{2}$ in Ham's F-12 medium (Sigma-Aldrich, St Louis, MO) supplemented with $10 \%$ heat-inactivated fetal bovine serum by the method described previously. ${ }^{15}$

Assay for TG synthesis activity using CHO-K1 cells Assays for TG and CE synthesis using CHO-K1 cells were carried out using established methods ${ }^{20}$ with some modifications. CHO-K1 cells $\left(1.25 \times 10^{5}\right.$ cells per $\left.250 \mu \mathrm{l}\right)$ were cultured in a 48 -well plastic microplate. A sample $\left(2.5 \mu \mathrm{l}\right.$ in methanol) and $\left[1-{ }^{14} \mathrm{C}\right]$ oleic acid ( $1 \mathrm{nmol}, 1.85 \mathrm{kBq}, 5.0 \mu \mathrm{l}$ in $10 \%$ ethanol/phosphate-buffered saline solution) were added to each well of the culture. The cells were cultured at $37^{\circ} \mathrm{C}$ in $5.0 \% \mathrm{CO}_{2}$. After 6-h incubation, cells in each well were washed twice with phosphate-buffered saline. The cells were lysed by adding $0.25 \mathrm{ml}$ of $10 \mathrm{~mm}$ Tris- $\mathrm{HCl}(\mathrm{pH} 7.5)$ containing $0.10 \%$ (w/v) sodium dodecyl sulfate, and the cellular lipids were extracted by Bligh and Dyer's method. ${ }^{21}$ The total lipids were separated on a TLC plate (silica gel F254, $0.50 \mathrm{~mm}$ thick; Merck,) and analyzed with a bioimaging analyzer (BAS 2000; Fujifilm, Tokyo, Japan) to measure the amount of $\left[{ }^{14} \mathrm{C}\right]$ lipids. Lipid synthesis activity (\%) was defined as $\left(\left[{ }^{14} \mathrm{C}\right]\right.$ lipid-sample/ $\left[{ }^{14} \mathrm{C}\right]$ lipid-control $) \times 100$. The $\mathrm{IC}_{50}$ value was defined as the drug concentration causing $50 \%$ inhibition of lipid synthesis.

\section{Assay for DGAT activities in CHO-K1 microsomes}

The assay for TG synthesis activity using $\mathrm{CHO}-\mathrm{K} 1$ microsomes was carried out by our established method. ${ }^{14,15}$ Briefly, the reaction mixture contained $175 \mathrm{~mm}$ Tris- $\mathrm{HCl}(\mathrm{pH} 8.0), 50 \mu \mathrm{g}$ protein of microsomal fraction, $120 \mu \mathrm{M}$ BSA, $14 \mu \mathrm{M}$ palmitoyl-CoA, $1.7 \mu \mathrm{M}$ [1$\left.{ }^{14} \mathrm{C}\right]$ palmitoyl-CoA $(0.74 \mathrm{kBq}$ GE Healthcare UK, Buckinghamshire, England), $8.0 \mathrm{~mm} \mathrm{MgCl}_{2}, 2.5 \mathrm{~mm}$ diisopropyl fluorophosphates and $150 \mu \mathrm{M}$ 1,2-dioleoyl-sn-glycerol (Sigma-Aldrich) and a test sample $(5.0 \mu \mathrm{l}$ in $\mathrm{MeOH})$ in a total volume of $0.20 \mathrm{ml}$. The assay was initiated by the addition of a microsomal fraction. After 15-min incubation at $23^{\circ} \mathrm{C}$, the reaction was stopped by the addition of $\mathrm{CHCl}_{3}-\mathrm{MeOH}(1: 2$, $1.2 \mathrm{ml}$ ), and lipids were extracted by the Bligh and Dyer's method. ${ }^{21}$ The total lipids were separated on a TLC plate and analyzed with bioimaging to measure the amount of $\left[{ }^{14} \mathrm{C}\right] \mathrm{TG}$. DGAT activity (\%) was defined as $\left(\left[{ }^{14} \mathrm{C}\right] \mathrm{TG}\right.$-sample/[ $\left.{ }^{14} \mathrm{C}\right] \mathrm{TG}$-control $) \times 100$. The $\mathrm{IC}_{50}$ value was defined as the drug concentration causing $50 \%$ inhibition of DGAT activity.

\section{Cytotoxic assays}

Cytotoxicity of samples to $\mathrm{CHO}-\mathrm{K} 1$ cells was measured by the colorimetric assay using 3-(4,5-dimethylthiazo-2-yl)-2,5-diphenyltetrazolium bromide (MTT) (Sigma-Aldrich). CHO-K1 cells $\left(5.0 \times 10^{5}\right.$ cells in $100 \mu \mathrm{l}$ ) were added to each well of a 96-well micro plate. A sample $(1.0 \mu \mathrm{l}$ in $\mathrm{MeOH})$ was added to each well to make a final concentration of 0 to $92 \mu \mathrm{M}$. The cells were incubated for $6.0 \mathrm{~h}$ at $37^{\circ} \mathrm{C}$. MTT ( $10 \mu \mathrm{l}$ of $5.5 \mathrm{mg} \mathrm{ml}^{-1}$ stock solution) and lysis solution ( $90 \mu \mathrm{l}, 40 \% \mathrm{~N}, \mathrm{~N}$-dimethylformamide, $20 \%$ sodium dodecyl sulfate, $2.0 \% \mathrm{CH}_{3} \mathrm{COOH}$ and $0.030 \% \mathrm{HCl}$ ) were added to each well, and the microplate was shaken for $2.0 \mathrm{~h}$. The OD of each well was measured at $540 \mathrm{~nm}$ using a microtiter-plate reader (Elx 808; BioTek Instruments, Winooski, VT, USA). 

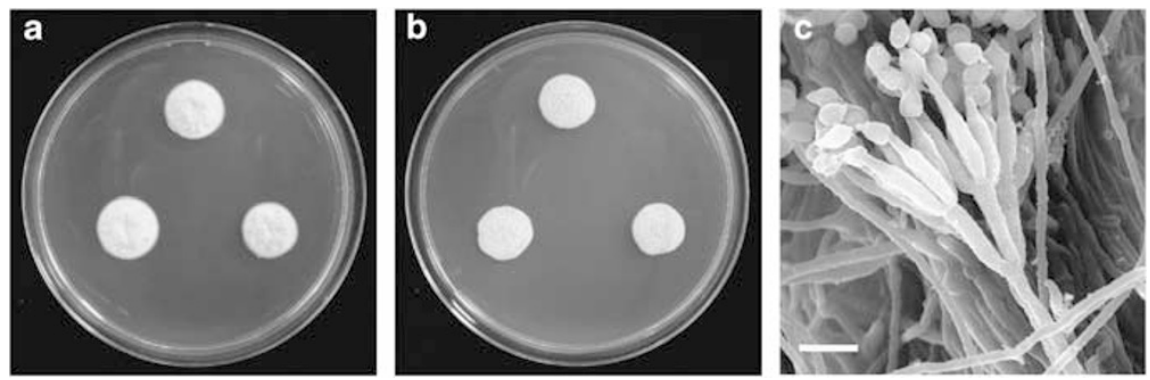

Figure 2 Morphological characteristics of the isochaetochromins-producing strain FKI-4942. (a) Photograph of colonies grown on CYA for 7.0 days. (b) Photograph of colonies grown on MEA for 7.0 days. (c) Scanning electron micrograph of conidiophore of strain FKI-4942. Bar represents $10 \mu \mathrm{m}$.

\section{RESULTS}

\section{Taxonomy of strain FKI-4942}

Colonies on CYA after 7 days at $25^{\circ} \mathrm{C}$ (Figure 2a) were $15-17 \mathrm{~mm}$ in diameter, radially sulcate, floccose, colliculose, with aerial mycelium and white (hue number; a) in color. The center of the colony was lemon yellow (hue number; 1 ia) in conidial color, without exudate drops. The reverse side was gold (hue number; 2 lc) with an entire margin, without soluble pigment. Colonies on MEA after 7 days at $25^{\circ} \mathrm{C}$ (Figure $2 \mathrm{~b}$ ) were $13-15 \mathrm{~mm}$ in diameter, less dense than on CYA, colliculose, with floccose aerial mycelium, and light yellow (hue number; 1 ea) in color, exuding sparse clear drops. The reverse side was golden yellow $(2 \mathrm{~kb})$ with an entire margin, without soluble pigment. Colonies on $\mathrm{G} 25 \mathrm{~N}$ at $25^{\circ} \mathrm{C}$ showed no growth. Colonies on CYA at $5{ }^{\circ} \mathrm{C}$ and $37^{\circ} \mathrm{C}$ showed no growth.

Conidiophores on MEA were borne on a basal felt or directly from the agar, and stipes were simple or rarely branching, (15-)20-65×1.7-3.7 $\mu \mathrm{m}$, with a heavy wall. Penicilli were typically biverticillate (Figure $2 \mathrm{c}$ ). Metulae were in whorls of 2-4, individually more or less cylindrical across the top, and about 11.6-18.6×(1.1-)1.5$2.5 \mu \mathrm{m}$ in size. They were usually rather appressed, or sometimes slightly divergent when forced apart by larger whorls. Phialides were ampulliformed $11.4-19.6 \times 1.2-3.0 \mu \mathrm{m}$ in size, and conidiogenous were apertured $0.5-1.5 \mu \mathrm{m}$ wide. Conidia were subglobose to ellipsoidal or fusiform, slightly roughened, (1.9-)2.7-3.8 $\times(1.2-) 1.5-2.7 \mu \mathrm{m}$ in size, and with chains.

The total length of the rDNA ITS (including 5.8S rDNA) of FKI4942 was 580 bp. In a BLAST search using blastn from the National Center for Biotechnology Information (NCBI), ${ }^{22}$ the sequence of FKI-4942 had a $94.8 \%$ match (30 nucleotide sequence difference) with that of Penicillium variabile FRR 1290 (GenBank accession number AY373936).

From the results of morphological characteristics and BLAST search, the producing strain FKI-4942 was considered to belong to the genus Penicillium.

\section{Isolation of isochaetochromins}

The 13-day-old culture broth (2.01) was extracted with 2.01 of acetone. After acetone extracts were filtered and concentrated to remove acetone, the aqueous solution was extracted with 2.01 of ethyl acetate. The extracts were dried over $\mathrm{Na}_{2} \mathrm{SO}_{4}$ and concentrated in vacuo to dryness to yield a yellow brown material $(1.1 \mathrm{~g})$. The material was dissolved in a small amount of $\mathrm{CHCl}_{3}$ and applied to a silica gel column $(100 \mathrm{~g})$ previously equilibrated with $\mathrm{CHCl}_{3}$ and eluted stepwise with $\mathrm{CHCl}_{3}-\mathrm{MeOH}$ solutions $(200 \mathrm{ml} \times 2$ each, 100:0, 100:1, $50: 1,10: 1,1: 1,0: 100)$. The second fraction of 50:1 $\left(\mathrm{CHCl}_{3}-\mathrm{MeOH}\right)$ was concentrated in vacuo to dryness to yield a yellow brown material

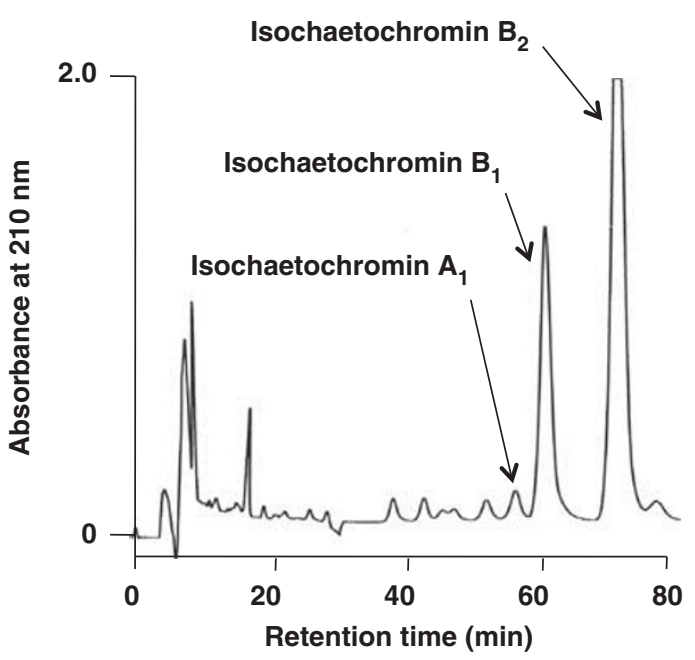

Figure 3 Chromatographic profile of isochaetochromin isolation by preparative HPLC. (HPLC conditions: column, PEGASIL ODS, $20 \times 250 \mathrm{~mm}$; Senshu Scientific; solvent, $55 \%$ MeCN containing $0.050 \%$ trifluoroacetic acid; detection, UV at $210 \mathrm{~nm}$; flow rate, $8.0 \mathrm{ml} \mathrm{min}^{-1}$ ).

(81 mg), which was finally purified by preparative HPLC (column, PEGASIL ODS, $20 \times 250 \mathrm{~mm}$; Senshu Scientific, Tokyo, Japan; solvent, $55 \% \mathrm{MeCN}$ containing $0.050 \%$ trifluoroacetic acid; detection, UV at $210 \mathrm{~nm}$; flow rate, $8.0 \mathrm{ml} \mathrm{min}^{-1}$ ). Under these conditions, isochaetochromins $A_{1}, B_{1}$ and $B_{2}$ were eluted as peaks with retention times of 57,62 and $74 \mathrm{~min}$, respectively (Figure 3 ). The fractions of the peaks were collected and concentrated to remove $\mathrm{MeCN}$. The aqueous solution was extracted with EtOAc, and the organic layer was concentrated to dryness to give isochaetochromins $A_{1}(2.5 \mathrm{mg}), B_{1}$ (14 $\mathrm{mg})$ and $\mathrm{B}_{2}(26 \mathrm{mg})$ as yellow powders.

\section{Effects of isochaetochromins on TG and CE synthesis in CHO-K1} cells

Effects of all isochaetochromins on TG and CE synthesis were evaluated using a cell-based assay to quantify $\left[{ }^{14} \mathrm{C}\right] \mathrm{TG}$ and $\left[{ }^{14} \mathrm{C}\right] \mathrm{CE}$ from $\left[{ }^{14} \mathrm{C}\right]$ oleic acid in $\mathrm{CHO}-\mathrm{K} 1$ cells. As shown in Figure 4, isochaetochromins $A_{1}, B_{1}$ and $B_{2}$ inhibited $\left[{ }^{14} \mathrm{C}\right] \mathrm{TG}$ synthesis with $\mathrm{IC}_{50}$ values of $33,5.6$ and $11 \mu \mathrm{M}$, respectively, and $\left[{ }^{14} \mathrm{C}\right] \mathrm{CE}$ synthesis with $\mathrm{IC}_{50}$ values of 50,58 and $44 \mu \mathrm{M}$, respectively. Isochaetochromins $A_{1}$ and $B_{1}$ showed no cytotoxic effect up to $92 \mu \mathrm{M}$, whereas only isochaetochromin $B_{2}$ weakly inhibited cell growth with an $\mathrm{IC}_{50}$ value of $60 \mu \mathrm{M}$. In this cell-based assay, isochaetochromin $\mathrm{B}_{1}$ is the most selective inhibitor of TG synthesis. 

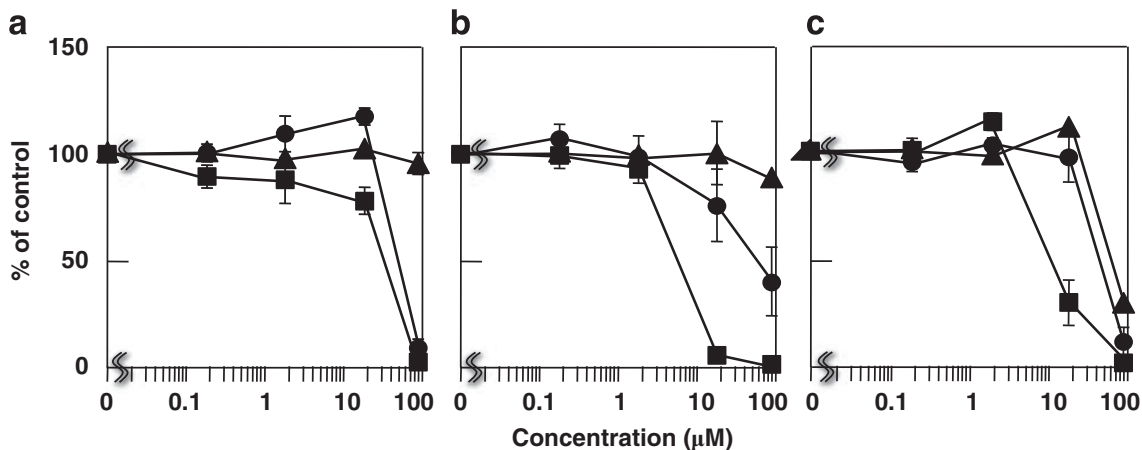

Figure 4 Effects of isochaetochromins on TG synthesis, CE synthesis and toxicity in CHO-K1 cells. (a) isochaetochromin $A_{1}$, (b) isochaetochromin $B_{1}$ and (c) isochaetochromin $\mathrm{B}_{2} \cdot\left[{ }^{14} \mathrm{C}\right] \mathrm{TG}(\mathbf{\square}),\left[{ }^{14} \mathrm{C}\right] \mathrm{CE}(\bullet)$ and cytotoxicity $(\mathbf{\Lambda})$. Error bars: \pm s.d. $(n=4)$

Table 1 Effects of isochaetochromins on TG synthesis, CE synthesis and cytotoxicity in CHO-K1 cells, and DGAT activity in microsomes prepared from $\mathrm{CHO}-\mathrm{K} 1$ cells

\begin{tabular}{lcccc}
\hline & \multicolumn{4}{c}{$I_{50}(\mu \mathrm{M})$} \\
\cline { 2 - 5 } Compound & $T G$ & $C E$ & Cytotoxicity & DGAT \\
\hline Isochaetochromin $\mathrm{A}_{1}$ & 33 & 50 & $>92$ & 320 \\
Isochaetochromin $\mathrm{B}_{1}$ & 5.6 & 58 & $>92$ & 190 \\
Isochaetochromin $\mathrm{B}_{2}$ & 11 & 44 & 60 & 310 \\
\hline
\end{tabular}

Abbreviations: CE, cholesteryl ester ; DGAT, diacylglycerol acyltransferase; TG, triacylglycerol.

\section{Effect of isochaetochromins on DGAT activity}

DGAT is the enzyme catalyzing the final step of TG synthesis. ${ }^{9}$ DGAT was considered a potential target of isochaetochromins in the inhibition of TG synthesis; therefore, the effect of isochaetochromins $A_{1}, B_{1}$ and $\mathrm{B}_{2}$ on DGAT activity was evaluated in microsomes prepared from CHO-K1 cells. As a result, isochaetochromins $A_{1}, B_{1}$ and $B_{2}$ were found to inhibit DGAT activity in a dose-dependent manner, but the $\mathrm{IC}_{50}$ values were rather high (Table 1).

\section{DISCUSSION}

As described in the accompanying paper, ${ }^{23}$ these compounds have the same planar bis-naphtho- $\gamma$-pyrone structure and are different in the stereochemistry of $2 / 2^{\prime}$ and $3 / 3^{\prime}$ methyl residues and the aS/aR-type axis, although not specified in Figure 1. These subtle differences appeared to affect the TG synthesis, CE synthesis and cytotoxicity in CHO-K1 cells (Table 1). Namely, isochaetochromin $B_{1}$ showed the highest selectivity in TG synthesis inhibition $\left(\mathrm{IC}_{50}, 5.6 \mu \mathrm{M}\right)$ when compared with $\mathrm{CE}$ synthesis inhibition $\left(\mathrm{IC}_{50}, 58 \mu \mathrm{M}\right)$. Isochaetochromin $A_{1}$ was found to be a moderate dual inhibitor of TG and CE synthesis in this assay. Isochaetochromin $\mathrm{B}_{2}$ seemed rather selective in TG synthesis inhibition, but showed a cytotoxic effect on $\mathrm{CHO}-\mathrm{K} 1$ cells at higher concentrations; therefore, although it is difficult to explain the biological activity of this compound, this planar structure might have intrinsic potential to affect CE synthesis, and the $a S$ axis structure (only isochaetochromin $\mathrm{B}_{1}$ ) might be responsible for the selective inhibition of TG synthesis in this assay. Regarding the inhibition of TG synthesis, DGAT is considered one of the potential targets; however, DGAT inhibitory activity of isochaetochromins was very weak in microsomes of CHO-K1 cells although they showed dose-dependent inhibition. It might be that isochaetochromins have distinct or multiple targets to exhibit TG/CE synthesis inhibition.

\section{ACKNOWLEDGEMENTS}

We express our thanks to Dr K Hanada (National Institute of Infectious Diseases, Tokyo, Japan) for kindly providing CHO-K1 cells. This work was supported by a grant-in-aid for Scientific Research (B) 18390008 (to HT) from the Ministry of Education, Culture, Sports, Science and Technology of Japan and by the Uehara Memorial Foundation (to HT).

1 Bray, G. A. et al. A double-blind randomized placebo-controlled trial of sibutramine. Obes. Res. 4, 263-270 (1996).

2 Rinaldi, C. M. et al. SR141716A, a potent and selective antagonist of the brain cannabinoid receptor. FEBS. Lett. 350, 240-244 (1994).

3 Davidson, M. H. et al. Weight control and risk factor reduction in obese subjects treated for 2 years with orlistat: a randomized controlled trial. J. Am. Med. Assoc. 281, 235-242 (1999).

4 Kopelman, P. et al. Cetilistat (ATL-962), a novel lipase inhibitor: a 12-week randomized, placebo-controlled study of weight reduction in obese patients. Int. J. Obes. 31, 494-499 (2007)

5 Smith, S. J. et al. Obesity resistance and multiple mechanisms of triglyceride synthesis in mice lacking Dgat. Nat. Genet. 25, 87-90 (2000).

6 Tomoda, H. \& Ōmura, S. Potential therapeutics for obesity and atherosclerosis: inhibitors of neutral lipid metabolism from microorganisms. Pharmacol. Ther. 115, 375-389 (2007)

7 Matsuda, D. \& Tomoda, H. DGAT inhibitors for obesity. Curr. Opin. Invest. Drug 8, 836-841 (2007)

8 Coleman, R. A. \& Lee, D. P. Enzymes of triacylglycerol synthesis and their regulation. Prog. Lipid Res. 43, 134-176 (2004).

9 Cases, S. et al. Identification of a gene encoding an acyl CoA:diacylglycerol acyltransferase, a key enzyme in triacylglycerol synthesis. Proc. Natl Acad. Sci. USA 95, 13018-13023 (1998)

10 Casaschi, S., Rubio, B. K., Maiyoh, G. K. \& Theriault, A. G. Inhibitory activity of diacylglycerol acyltransferase (DGAT) and microsomal triglyceride transfer protein (MTP) by the flavonoid, taxifolin, in HepG2 cells: potential role in the regulation of apolipoprotein B secretion. Atherosclerosis 176, 247-253 (2004)

11 Lee, S. W. et al. New polyacetylenes, DGAT inhibitors from the roots of Panax ginseng. Planta Med. 70, 197-200 (2004).

12 Ōmura, S. et al. Roselipins, novel fungal metabolites having a highly methylated fatty acid modified with a mannose and an arabinitol. J. Antibiot. 52, 586-589 (1999).

13 Tabata, N., Ito, M., Tomoda, H. \& Ōmura, S. Xanthohumols, diacylglycerol acyltransferase inhibitors, from Humulus lupulus. Phytochemistry 46, 683-687 (1997).

14 Tomoda, H. et al. Amidepsines, inhibitor of diacylglycerol acyltransferase produced by Humicola sp. FO-2942. I. Production, isolation, and biological properties. J. Antibiot. 48, 937-941 (1995).

15 Ohte, S. et al. Dinapinones, novel inhibitors of triacylglycerol synthesis in mammalian cells, produced by Penicillium pinophilum FKI-3864. J. Antibiot. 64, 489-94 (2011).

16 Singh, S. B. et al. Four novel bis-(naphtho-gamma-pyrones) isolated from Fusarium species as inhibitors of HIV-1 integrase. Bioorg. Med. Chem. Lett 13, 713-717 (2003).

17 Pitt, J. I. The Genus Penicillium, and its Teleomorphic States Eupenicillium and Talaromyces 1-634 (Academic Press, London, 1979).

18 Jacobson, E., Granville, W. C. \& Foss, C. E. Color harmony manual 4th edn. (Container of America, Chicago, 1958)

19 White, T. J., Bruns, T., Lee, S. \& Taylor, J. W. in Amplification and direct sequencing of fungal ribosomal RNA genes for phylogenetics. PCR protocols: a guide to methods and applications (eds Innis MA, Gelfand RH, Sninsky JJ, White TJ) 315-332 (Academic Press, New York, 1990) 
20 Ohshiro, T., Rudel, L. L., Ōmura, S. \& Tomoda, H. Selectivity of microbial acyl-CoA: cholesterol acyltransferase inhibitors toward isozymes. J. Antibiot. 60, 43-51 (2007).

21 Bligh, E. G. \& Dyer, W. J. A rapid method of total lipid extraction and purification. Can. J. Biochem. Physiol. 37, 911-917 (1959).
22 Altschul, S. F., Gish, W., Miller, W., Myers, E. W. \& Lipman, D. J. Basic local alignment search tool. J. Mol. Biol. 215, 403-410 (1990).

23 Ugaki, N., Yamazaki, H., Uchida, R. \& Tomodam, H. New isochaetochromin, an inhibitor of triacylglycerol synthesis in mammalian cells, produced by Penicillium sp. FKI-4942: II. Structure elucidation. J. Antibiot. 65, 21-24 (2012). 